\title{
Liver Kidney Microsomal Type 1 IgG Antibody Measurement
}

National Cancer Institute

\section{Source}

National Cancer Institute. Liver Kidney Microsomal Type 1 IgG Antibody Measurement. NCl Thesaurus. Code C100454.

The determination of the amount of liver kidney microsomal type 1 Ig G antibody present in a sample. 